\title{
SOLAR DECATHLON EUROPE 2019 - MAGYAR FÉSZEK+ PROJEKT BEMUTATÁSA
}

\author{
Pintér Judit Mária \\ adjunktus, Automatizálási és Infokommunikációs Intézet \\ 3515 Miskolc, Miskolc-Egyetemváros, e-mail: pinterjm@uni-miskolc.hu
}

\begin{abstract}
Absztrakt
Miskolc, Pécs és az algériai Blida egyetemeinek kreativ hallgatói és oktatói a Solar Decathlon Europe 2019 versenyén egy új „magyar-energia-projekt” magalkotását tüzték ki célul. A verseny kiirrója szerint közel 800.000 idejétmúlt, fizikailag leamortizálódott „,Kádár - kocka” vár a XXI. század kihívásainak való megfeleltetésre. A Solar Decathlon Europe 2019 verseny nem csak egy izgalmas lehetöséget kinált azon kísérlet levezetésére, hogy miként lehet egy új, minöségi irányvonalat mutatni az öröklött épitészeti környezet fenntartható fejlesztésére és az új épitészeti irányok meghatározására, hanem remek lehetöség volt mind a hallgatók, mind az oktatók számára, hogy megmérettessenek, tapasztalatot szerezzenek és nemzetközi kapcsolatokat épitsenek.
\end{abstract}

Kulcsszavak: nemzetközi verseny, épületautomatizálás, IoT, okosotthon

\begin{abstract}
The creative students and educators from University of Miskolc, University of Pécs, and the Algerian University of Bilda, set their goal, to create a new ",Hungarian-energy-project”. According to the announcer of the competition, there are 800.000 obsolete, physically amortise "Kádár-cubes" waiting for reconstruction to meet the challenges of the XXI. century. The Solar Decathlon Europe 2019 competition not only provided an exciting opportunity to lead an experiment on how to set a new highquality policy for sustainable development of the inherited architectural environment and to define new architectural directions, it was also a great opportunity for students and teachers alike to complete, gain experience and build international relationships.
\end{abstract}

Keywords: international competition, building automation, IoT, smart home

\section{Bevezetés}

A Solar Decathlon Europe 2019 nemzetközi innovációs passzívház építő verseny központi célja a megújuló energiák, köztük kiemelten a napenergia (ahogyan az a verseny nevéből is adódik) és az innovatív technológiák alkalmazásával összefüggő építészeti megoldások népszerüsítése az egyetemista csapatok által felépített pályamüveken keresztül. A Solar Decathlon a Világ egyik legjelentősebb nemzetközi, egyetemek között megrendezett építőipari innovációs versenye. Az első Solar Decathlon versenyt az Amerikai Egyesült Államok Energiaügyi Minisztériuma (US Government, Department of Energy (DoE)) kezdeményezésére 2002-ben tartották meg Washingtonban. A kezdeményezés alapvető célja, hogy a fiatalok kreativitására és innovációs képességére építve egyetemi kutatók és fejlesztők múködjenek együtt más egyetemekkel, ipari partnerekkel, szponzorokkal és olyan innovatív, energiahatékony házakat tervezzenek, amelyek a megújuló energia és a tudatos erőforrás használatra 
alapozva, fenntarthatóságot demonstráló mintaotthonok lehetnek [2]. Az alábbi fejezetekben tömören összefoglalva bemutatásra kerül az idei verseny koncepciója és a megmérettetésben figyelembe vett szempontok, valamint a 3 egyetem konzorciumából álló SOMEshine csapat pályamunkája és tapasztalatai.

\section{Solar Decathlon Europe 2019}

A verseny során a hallgatók nem csak terveket készítenek, hanem az aktuális döntő helyszínén meg is építik a kiválasztásra kerülő pályamüveket. Így idén a verseny eredményeképpen egy innovatív lakóházakat bemutató "mintaházpark" jött létre Szentendrén, amelyet nem csak a szakma, de a lakosság is látogathatott.

Miközben a versenyre megépülö házak megjelenésükben és tulajdonságaikban általában sokfélék, mindegyikük jellemzően a mai kor igényeit kielégítő - élhető, környezetbarát módon fenntartható/önfenntartó, emberközpontú - otthon, mely esztétikus formában ötvözi a modern, praktikus és fenntartható családi (minta)ház jellemzőit. Az idei verseny fő célkitüzése az egyes országok renovációs problémáinak a bemutatása és arra adott megoldások népszerúsítése volt, amelyre 2017 novemberében lehetett pályázatot benyújtani. Minden csapat saját országának kihívásaira reagált pályamunkáján keresztül. A bejutást elnyerő csapatok elöször dokumentációk és tervek formájában készítették el, majd 2019 június 28.-tól 14 nap állt a csapatok rendelkezésére, hogy megépítsék házukat, amiket 2 héten keresztül versenyeztettek egymással.

\subsection{Versenyszámok}

A pályamüveket a 2 hetes és az azt megelőző tervezési időszakban az alábbi 10 szempont alapján vizsgálták [3]:

- Építészet

- Mérnöki tervezés és kivitelezés

- Energiahatékonyság

- Kommunikáció és társadalmi figyelemfelhívás

- Városszövetbe illesztés és hatás

- Innováció es életképesség

- Cirkularitás és fenntarthatóság

- Komfortfeltételek

- Lakóház-funkcionalitás

- Energiamérleg

Egy-egy kategórián belül 100 pontot lehetett elérni. 10 kategóriából 7 esetben nemzetközi zsüri előtt kellett a csapatoknak munkájukat prezentálni körbevezetéssel egybekötve. Minden egyes kategóriánál más, az adott szakterület jeles képviselői alkották a zsürit. 3 kategóriában (komfortfeltételek, lakóházfunkcionalitás, energiamérleg) egzakt mérések és feladatok elvégzése alapján adódtak össze a pontok. Minden kategóriában az első három helyezést díjazták, valamint az összesített pontozás alapján az első három abszolút gyöztest is.

\section{SOMEshine csapat}

A Miskolci Egyetem által vezetett konzorcium összetétele és versenykoncepciója a közel 2 éves időszak alatt jelentős változásokon ment keresztül. A csapat végső összetételét a Miskolci Egyetem, a 
Pécsi Tudományegyetem és az algériai Blidai Egyetem alkotta. A csapattagok a 14 napos építés alatt egy emberként dolgoztak napi 16 órában, hogy megvalósuljon mindaz, amit megálmodtunk. Az előkészületi időszakban az egyetemek az alábbi fő feladatokat végezték el:

- Miskolci Egyetem: projekt lebonyolítása, menedzseri feladatok ellátása, az automatizálási és informatikai rendszer megtervezése és előkészítése.

- Pécsi Tudományegyetem: az épület megtervezése, a gépészet megtervezése és elökészítése, energiahatékonysági vizsgálatok/szimulációk végzése.

- Blidai Egyetem: energetikai szimulációk, belsőépítészeti koncepciók és a kötelező dokumentációk készítése.

A csapat közel 80 föből állt 65 ipari partner/szponzor, számtalan kolléga és barát segítette idöszakosan munkánkat. Az alábbi képen a többszörösen díjazott csapat törzstagjai láthatóak.

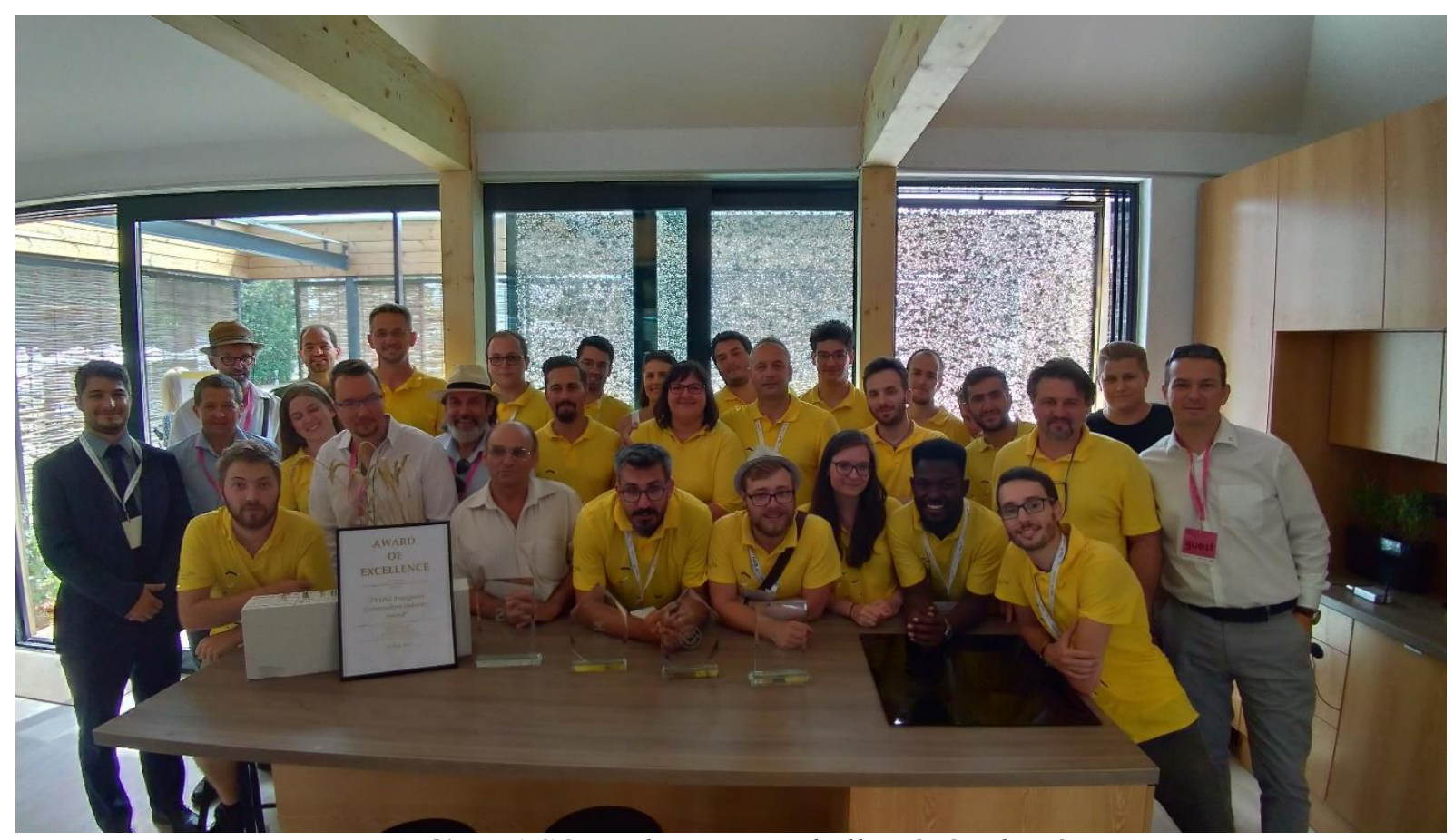

\section{1. ábra. A SOMEshine csapat hallgatói és oktatói}

A verseny remek lehetőséget nyújtott, hogy a gyakorlatban is megmutatkozzon az egyetemek közötti együttmüködés sikeressége, nem csak hazai, hanem nemzetközi vonalon is. Ezért a verseny adta lehetőségeket folytatva új kutatási irányokat meghatározva folytatjuk közös munkánkat a jövőben.

\section{Magyar Fészek+ projekt}

Csapatunk a magyarországi tipikus kockaházak renovációját helyezte középpontba és versenyépületével annak problémáira reagált, valamint továbbfejlesztette azt, egy passzív korszerü építészeti és technológiai megoldásokat tartalmazó otthonná. Projektünk, ahogy azt a pályázat kiírása és a verseny építészeti jellege is diktálta két irányban indult el. Az egyik irány az alacsony költségvetésủ passzív, vernakuláris elemek energiahatékony beépítésével megfogalmazott épületfelújítás, míg a másik irány 
az előző elemeket kiegészítő technológiai tudással párosított plusz energiás új épület a Magyar Fészek+ megfogalmazása volt.

\subsection{Előzmények}

Az 1950-es évekre, hazánk falvainak és népi értékeket felsorakoztató külvárosainak lakóházállományát a szocialista lakásmegújító programmal sikerült szinte teljes mértékben felülírni. A hossztoldott vagy beforduló csürös, tornácos vályogházak helyébe, az új létforma igényeit tükrözni vágyó és a házgyárak által tömegével termelt „korszerü” építőanyagokat felhasználó „Kádár-kocka” lépett (2.-3. ábra). Bár a korabeli propaganda szerint az új típus-otthon minden szempontból előnyösebb volt korai társánál, rövid idő elteltével rájöhettünk annak számtalan hiányosságára. A vályog és faanyagot lecserélő kisméretű tégla szerkezetek hőszigetelő képessége sokkal rosszabb volt, a délre nyitott tornácos kialakítás helyett, mely a teljes építmény ökoszisztémáját egyszerü passzív eszközökkel rendezte, a Kádár kocka minden logikus érvet felrúgva szervezte tereit.

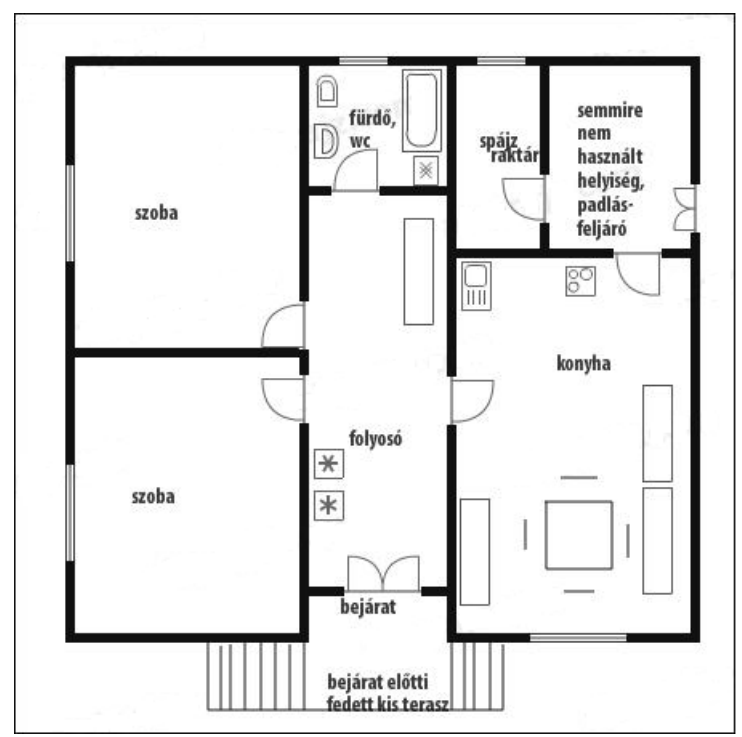

2. ábra. Egyik legelterjedtebb magyar kockaház alaprajza

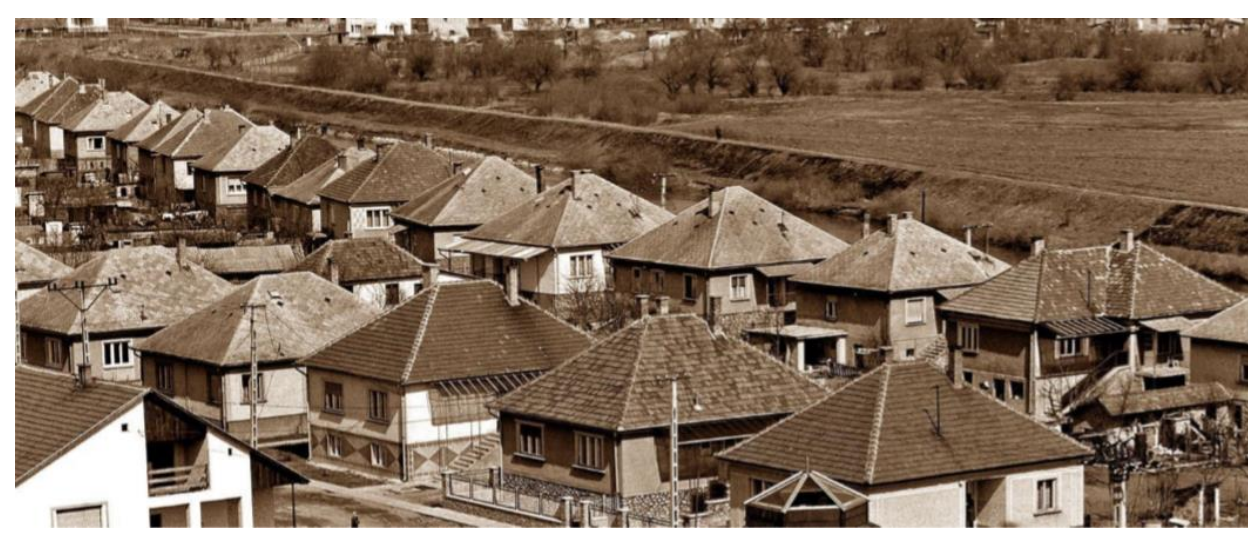

3. ábra. Tipikus magyar kockaházak (Edelény 1982) 


\subsection{Az eredeti építészeti koncepció újradefiniálása}

Első lépésként fel kellett mérnünk, milyen koncepció alapján válhat ökologikusan fenntartható, okos otthonná egy öröklött „Kádár-kocka”. Tudni kell, hogy a vizsgált épületek tájolása az esetek 95\%-ában nem veszi figyelembe a napenergia hasznosításának és az épület környezettel való kapcsolatának lehetőségét. Újrarendeztük az alaprajzot, zónákra bontottuk az épületet, melyek segítségével nemcsak a belső elrendezés intimitását tudtuk megszervezni, hanem a vizes rendszereket is egyszerüsíthettük (4. ábra).

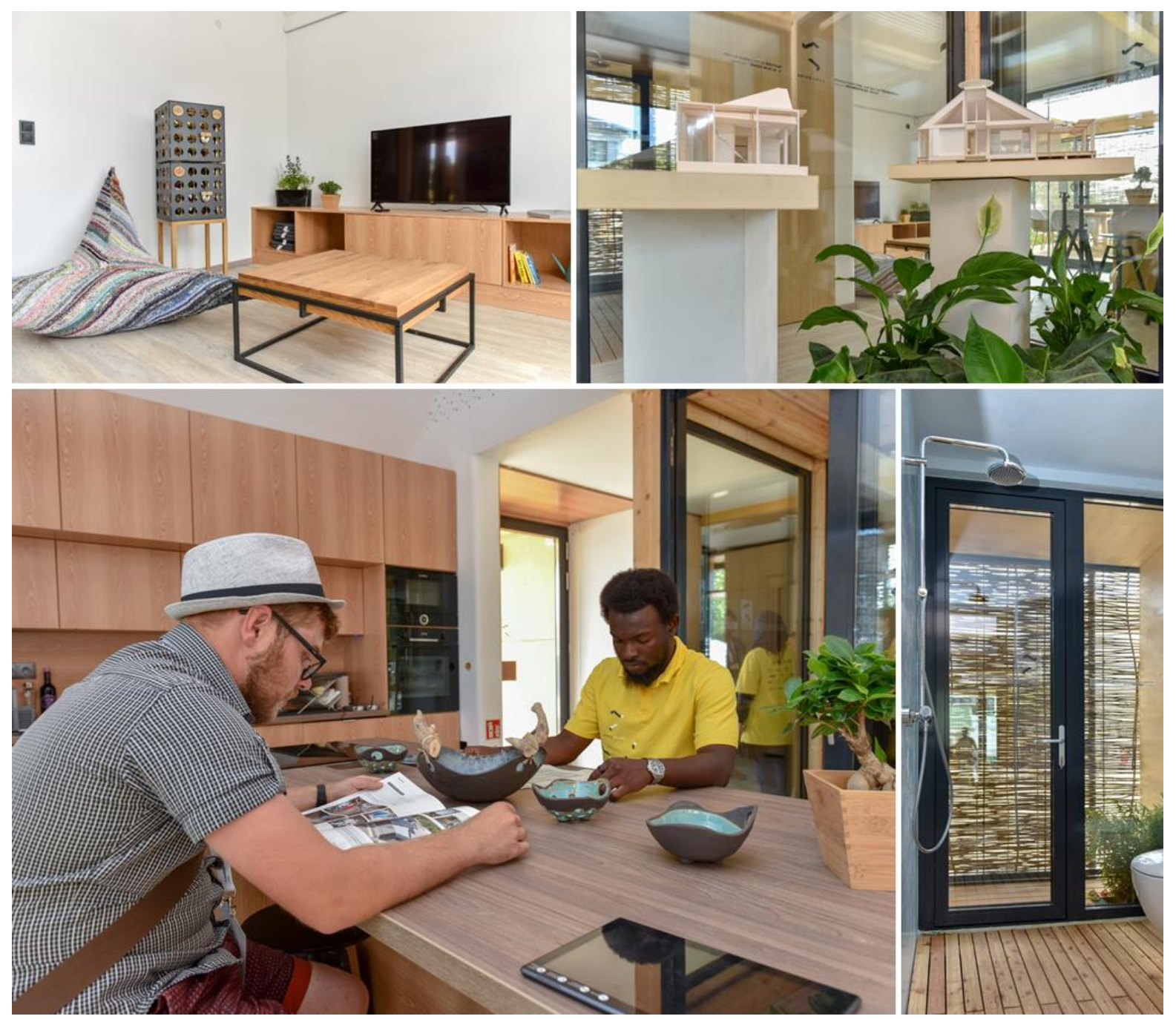

4. ábra. A megépült pályamunka belsö terei

Új típusú energiatereket hoztunk létre, mint például az épület alatt átvezetett, árnyékos területen paszszív módon hütött levegővel müködő Venturi Átrium.

Az épület hőháztartását az új, természetes anyagokból kialakított termikus burok (fonott árnyékoló rendszer / cellulóz höszigetelés) adja, míg a páraháztartást az épület belső szerkezeti felületeire húzott 
vályog / vályogrost lemezek beépítésével kialakított vakolatréteg adja. Az épületet körülvevő tolófalrendszer a kiterjesztett tér számtalan változatát rejti magában (5. ábra). A Venturi átriumban és a teraszon / ill. naptérben elhelyezett élőflóra a ház önfenntartó oxigénbázisa.

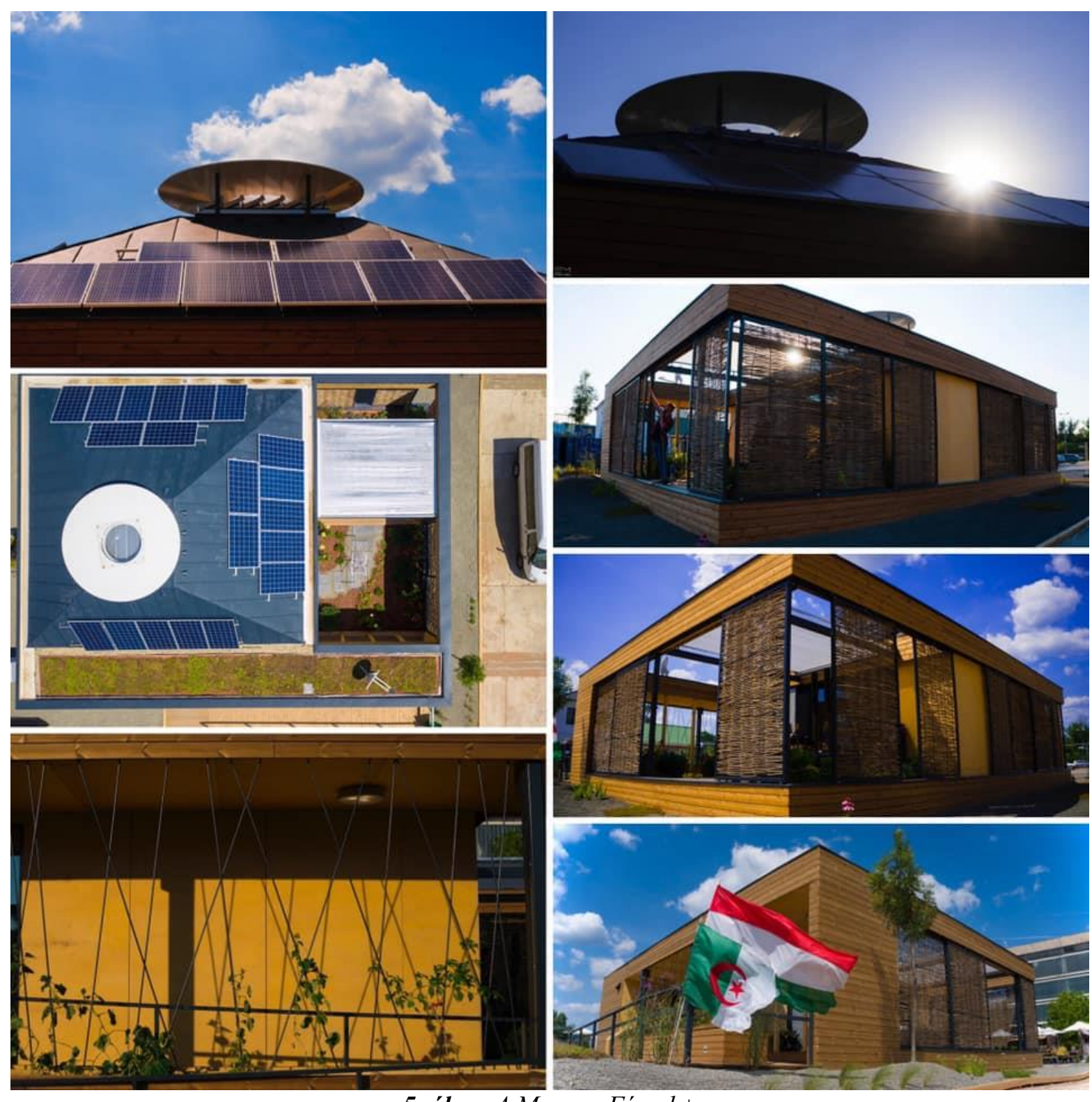

5. ábra. A Magyar Fészek+

\subsection{A ház automatizálási rendszere}

A Miskolci Egyetem hallgatóinak és oktatóinak feladata a projekt lebonyolítása és a menedzseri feladatok ellátása mellett az automatizálási és informatikai rendszer megtervezése és előkészítése volt. Az 
épületünk központi automatizálási és informatikai egységét egy Loxone rendszer képezi. A választásunk azért esett erre a rendszerre, mert a Loxonet korszerüség, komfortosság és biztonság jellemzi. Mindig ellenőrizhetjük lakásunkat, házunkat bárhol is legyünk a világban.

Mivel minden eszköz kapcsolható, és felügyelhető általa, ezért remek felületet képzett, hogy az alábbi egységeket integráljuk a rendszerbe (6-7. ábra):

- Világításvezérlés (Lighting control)

- Biztonsági rendszer (Security system)

- Energiamenedzsment (Energy management)[1]

- Épületgépészeti berendezések vezérlése (Controlling the HVAC system)

- Szenzorrendszer a levegőminőség és a fütés optimalizálása és felügyelete érdekében [4]

- Jelzö- és felügyeleti rendszer (Alarm and monitoring system)[1]

- Távvezérlés (Remote control): az épületfelügyeleti rendszer elérése mobil eszközökről

- Infokommunikációs akadálymentesítés megvalósítása hangvezérléssel

- Komfortérzet biztosítása

- Érzelem felismerés: az integrált prototípus modul nem a kimondott szavak értelmét vizsgálja, hanem a beszéd szupraszegmentális jellemzőit és a felismert érzelmi állapot alapján változtatjuk a ledes megvilágítás színét és indítunk el zenét [5]

\section{Energiamenedzsment}

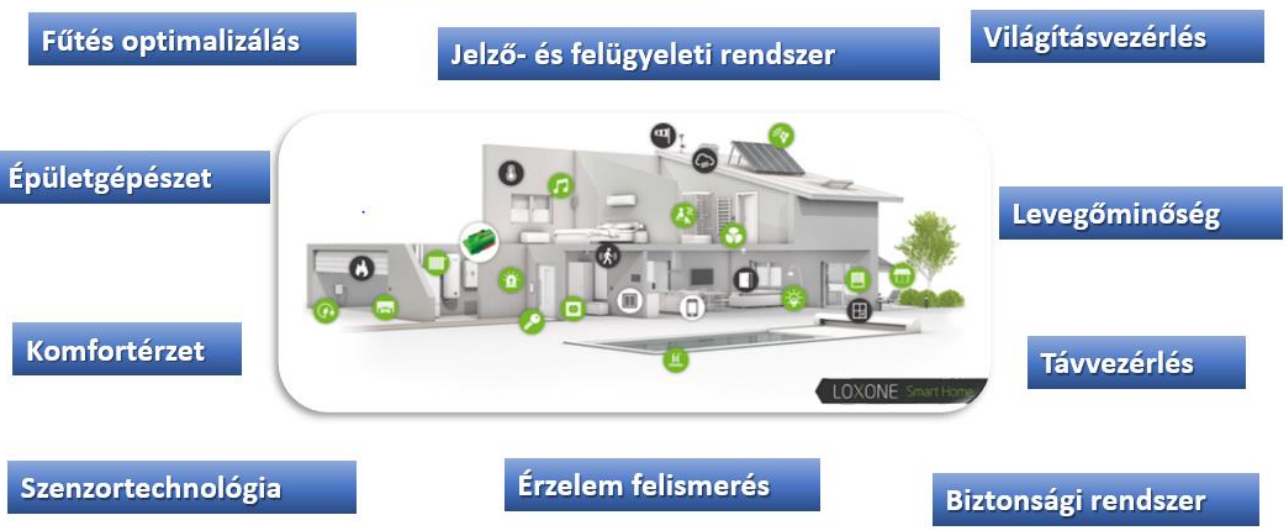

Infokommunikációs akadálymentesítés

\section{6. ábra. Az épület automatizálási rendszerének részei}

A 7. ábrán az automatizálási rendszer elhelyezkedése a gépészeti térben és főbb egységei láthatóak. A Loxone rendszer applikációja könnyen kezelhető és jól konfigurálható. A házban elhelyezett gépészet, világítás, a biztonsági kamerák kezelése és felvételeinek megtekintése szintén integrálható az alkalmazásba. A levegőminőségmérő szenzoros egységek értékeit nem csak az applikáción keresztül, hanem webes felületen keresztül is elérhetővé tettük. 

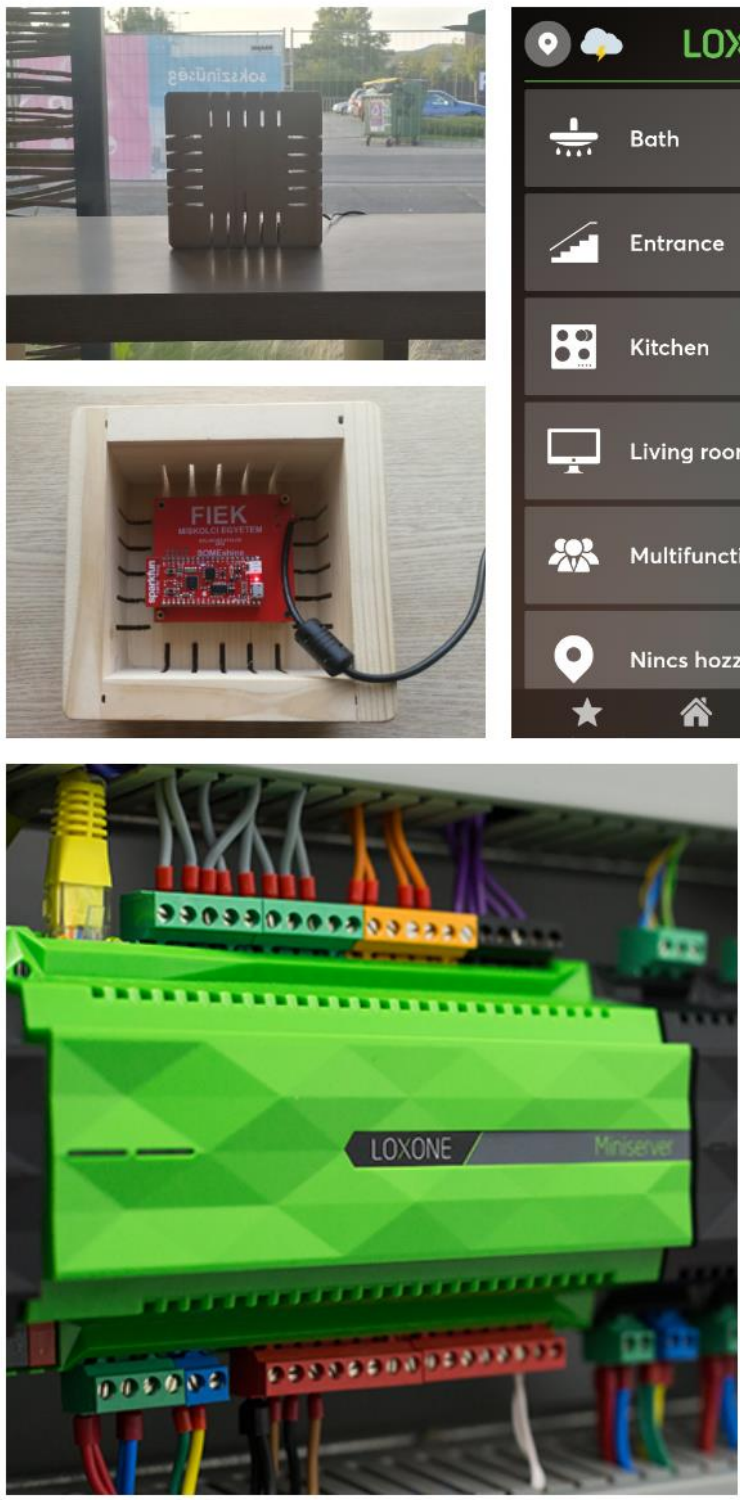

7. ábra. Az épület automatizálási rendszerének moduljai

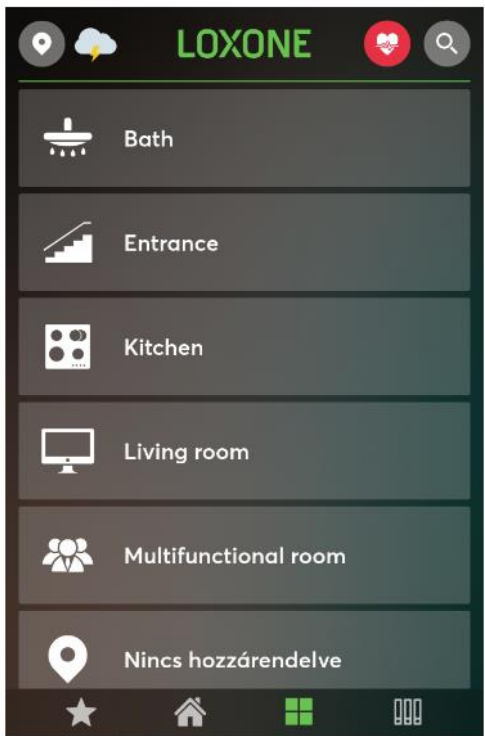

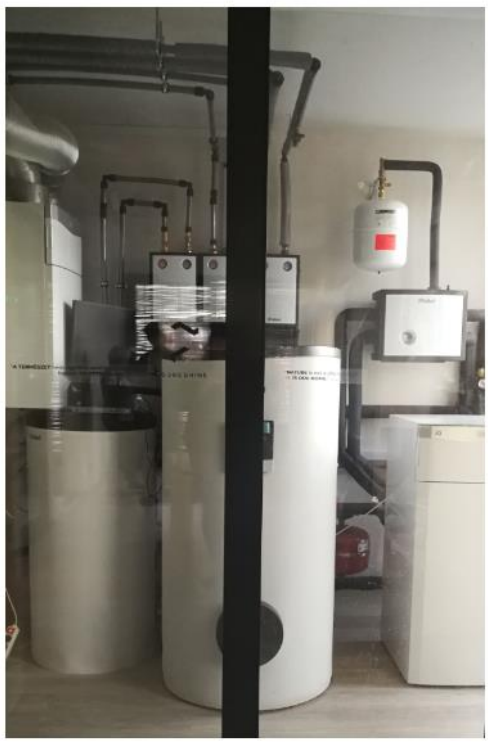

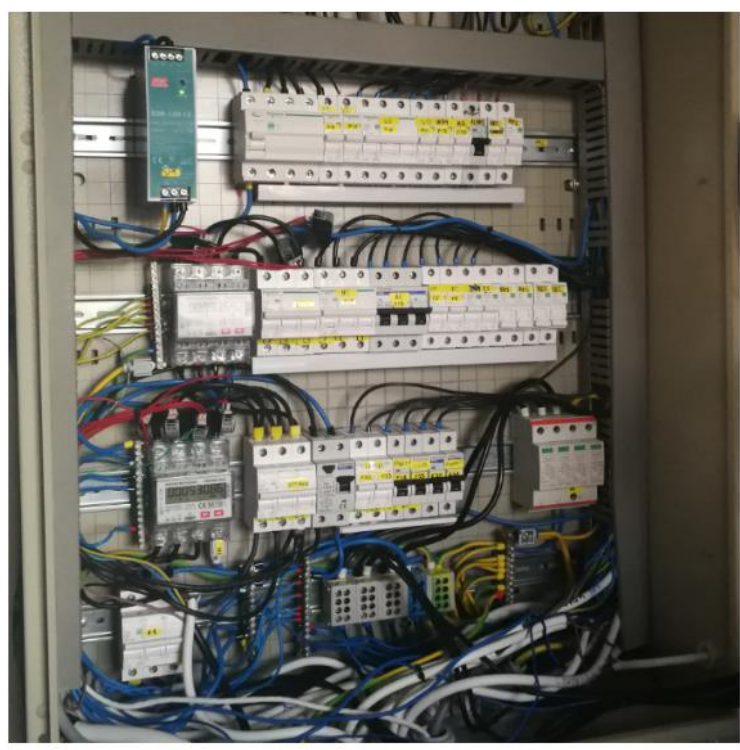

\section{5 Összefoglalás}

A publikációban bemutatásra kerültek a megvalósított prototípus épület létrejöttének lépései, a megvalósító csapat és a megépített pályamunka föbb részei. A közel 2 éves projekt óriási tapasztalatot jelentett nem csak a benne tevékenykedő embereknek, hanem az egyetemeknek is. Emberfeletti teljesítményt nyújtottak a hallgatók a 14 napon keresztül tartó építkezésen kilépve saját komfortzónájukból. Nem csak szakmai fejlődést jelentett számukra a részvétel, hanem önismeretet is. A projekt eredményeit közösen a hallgatókkal előadások és publikációk formájában tesszük közzé. Munkájukat ösztön- 
díj formájában honoráltuk és szakmai tárgyak beszámításánál figyelembe vettük teljesítményüket. A kutatási vonalakat folytatva TDK dolgozatok készítése folyamatban van.

Az egyetemek közötti sikeres együttmúködést pedig mi sem bizonyítja jobban, mint maga a projekt hazai sikere és az elnyert díjak:

- Energiahatékonyság kategória 3. helyezés

- Építészet kategória 2. helyezés

- Közösségért különdíj

- ÉVOSZ (Építési Vállalkozók Országos Szakszövetsége) különdíj

A versenynek és a közös munkának köszönhetően számos média platformon sikerült megjelennünk.

\begin{tabular}{|l|r|}
\multicolumn{2}{|c}{ 1. táblázat Média megjelenések szan } \\
\hline Hagyományos média: & \\
\hline A média megjelenésének becsült vagy számított száma & 18 \\
\hline nyomtatott kiadványok & 12 \\
\hline újságok & 27 \\
\hline online sajtó & 12 \\
\hline tévé & 13 \\
\hline rádió & 30 \\
\hline A nyomtatott sajtó teljes becsült tájékoztatása & 25 \\
\hline A becsült teljes tájékoztatás TV-n és rádión keresztül & 6300 \\
\hline Közösségi média: & 21529 \\
\hline A látogatók száma a projekt weboldalán & 1023 \\
\hline A csapat hozzászólásainak száma a közösségi média csatornáin & \\
\hline A projekt és a csapat követöinek száma a Facebook-on, Instagram-on, Twitter-en & \\
\hline
\end{tabular}

Célunk ezen együttmüködés megerősítése és kiterjesztése kutatási projektben és közös pályázatokban, valamint az oktatás terén való közös kooperációban.

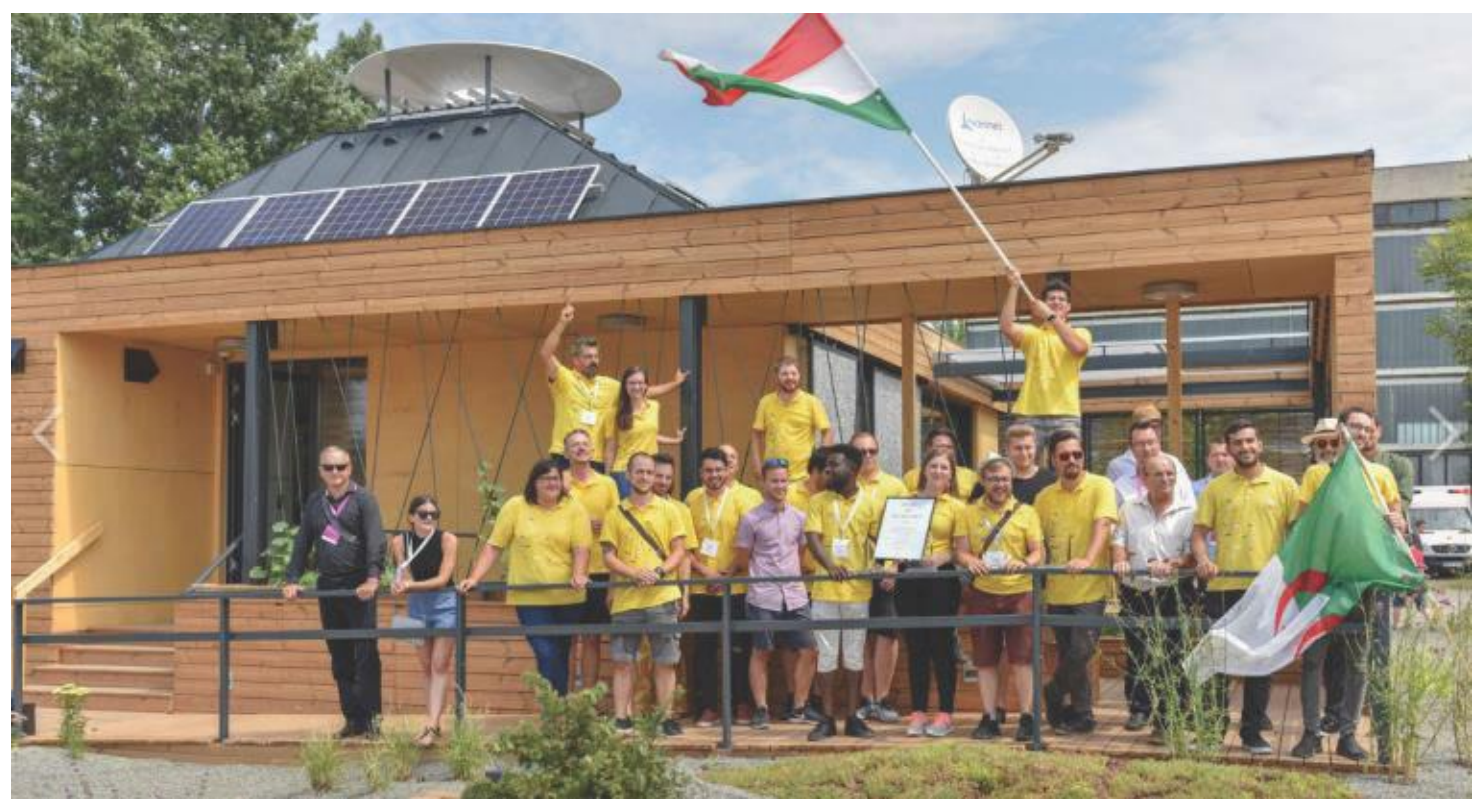

8. ábra. A sikeres nemzetközi együttmüködés eredménye 


\section{Köszönetnyilvánítás}

A cikkben ismertetett kutató munka az EFOP-3.6.1-16-2016-00011 jelü „Fiatalodó és Megújuló Egyetem - Innovatív Tudásváros - a Miskolci Egyetem intelligens szakosodást szolgáló intézményi fejlesztése" projekt részeként - a Széchenyi 2020 keretében - az Európai Unió támogatásával, az Európai Szociális Alap társfinanszírozásával valósul meg.

\section{IRODALOMJEGYZÉK}

[1] Forgács Zsófia: Intelligent control- and data acquisition methods with the requirements of industry 4.0. Doktoranduszok Fóruma: Gépészmérnöki és Informatikai Kar szekciókiadványa, Miskolc, Magyarország: Miskolci Egyetem Tudományos és Nemzetközi Rektorhelyettesi Titkárság, (2018) pp. 18-23.

[2] http://sde2019.hu Letöltve: 2020.05.24.

[3] http://solardecathlon.eu/wp/wp-content/uploads/2019/06/SDE19-RULES_V_3.1_22_06_19.pdf Letöltve: 2020.05.24.

[4] L. Kiss M., Báthory, Cs., Trohák, A., Palotás, Á.B.: Szállópor koncentráció mérő szenzorok összehasonlító elemzése. ENELKO 2018 XIX. Nemzetközi Energetika-Elektrotechnika Konferencia, Erdélyi Magyar Müszaki Tudományos Társaság (EMT), (2018) pp. 250-255.

[5] Pintér, J.M., Czap, L., L. Kiss, M.: Development of Speech-Based Interface for Smart Home Systems. Proceedings of the 19th International Carpathian Control Conference (ICCC 2018) IEEE, (2018) pp. 348-352. 